\title{
Entrepreneurship Education Curriculum and Framework for Its Implementation in Tertiary Institutions in Nigeria: Implication for Developing Entrepreneurial Mindset of Students
}

\author{
Francis Chidi Alinno (PhD) \\ Business Administration and Management Department, School of Business Studies, Akanu Ibiam Federal \\ Polytechnic Unwana, Ebonyi state, Nigeria
}

\begin{abstract}
Considering entrepreneurship Education Curriculum, modalities for implementation in tertiary institutions in Nigeria and its suggestions for developing the entrepreneurial mindset of the Students, twelve thousand eight hundred and seventy two (12872) students and lecturers/facilitators from Alex Ekwueme University, Ndufu Alike Ikwo, Akanu Ibiam federal Polytechnic, Unwana and Federal College of Agriculture Ishiagu, all in Ebonyi State formed the population. Given this population, a sample size of three hundred and eighty four was determined. Four hypotheses were tested with T-Distribution at 0.05 level of significance. Results of the tests amongst others showed that the pedagogical method for the entrepreneurship education in tertiary institution in Nigeria is not effective in developing the entrepreneurial mindsets of the students; poor implementation attitude, poor teaching techniques, poor infrastructural facility, corruption, inadequate funding etc impede the implementation of entrepreneurship education in tertiary institutions in Nigeria; current entrepreneurship curriculum in tertiary institutions in Nigeria is more theoretical and unsuitable for developing entrepreneurship practice; inability of the graduates to raise fund for actual entrepreneurship practice etc hamper entrepreneurship education as a mechanism for developing student's entrepreneurial skill. The author, recommend inclusion of school-based enterprises where students learn to identify potential business, plan, create and operate small business using the school as mini-incubators; employ teaching methods outside of the traditional teaching format, create opportunity for an experienced and a successful entrepreneur to visit the incubation center to interact with students as a way of exposing them to actual practice while core skills and values linked to entrepreneurship education should be a priority in initial teacher education programmes.
\end{abstract}

Keywords: Entrepreneurship, Entrepreneurship Education, Curriculum, Entrepreneurial mindset.

DOI: $10.7176 / \mathrm{JESD} / 11-22-04$

Publication date: November $30^{\text {th }} 2020$

\section{Introduction}

Starting and operating new business involves risks, efforts and the challenges of creating something new. In creating and growing a new venture, the entrepreneur assumes responsibility and risk for its development, survival and subsequently enjoys the reward there of. Researchers and experts promote entrepreneurship education as a major engine for economic growth and job creation among nation of the World. That is why individuals and governments today are encouraging entrepreneurship through various policies and programmes. Again entrepreneurship is increasingly being recognized as an important area of management study and practice. Its relevance is not confined to the context of new venture creation or the management of small businesses. Organizations of all sizes, and in all sectors, are requiring people to respond in ways that could be characterized as 'entrepreneurial'. These are evident in the increasing research on the subject as well as numerous seminars and workshop that are been undertaken by different organizations, individuals and government. It has also become a major course of learning in most tertiary institutions around the Globe (Okoro, 2008).

Today and in the context of Nigeria's present National Economic Empowerment Development Strategy (NEEDS) ideology, entrepreneurship has emerged from the seemingly unimportant position of the past to assume major significance as vital missing variables in our growth processes as a country. The importance of entrepreneurship to the sustainment of the growth of the economy via Gross National Product (GNP) and provision of job opportunity over the years has been recognized by the federal government. This could be evidenced from various policy pronouncements geared towards animating the dwindle fortunes of the economy. Even the industrial communities, international bodies such as the International Labour Organization (I.L.O) and European Economic Community as well as countries around the World have agreed to the vital role of entrepreneurship in their various policy statements concerning developing economy. The effect of entrepreneurial activities on economic growth and development has made entrepreneurship education gain worldwide recognition in countries such as United State of American, France, Germany, Britain e.t.c. As Gartner and Vesper (1994) rightly observed, more educational institution now offer a wide range of programmes on entrepreneurship. The programmes appear to be influencing and generating entrepreneurial interest amongst young graduates and eventually pushing them into business of their choice. Souitaris, Zerbinati, and Al-Laham, 
(2007); Zaralli and Rivenburgh (2016) reveal that entrepreneurial programmes raise attitudes and behaviours capable of provoking entrepreneurial intentions among youths who have interest in the economic development of their nation.

Nigeria's economy in the current global economy requires entrepreneurs with the requisite educational background to fire up the economic developmental need of the country. An entrepreneur is a man or woman from an upper or lower class background or a technologist. He or she could be a university or polytechnic graduate, a school dropout or perhaps an employee who create wealth for others as well as find better ways to utilize and reduce waste and who produces job others are glad to get. The present Nigerian economy is in dire need of the entrepreneurial mindset of the Chinese, Japanese, Americans, Germans and Britons. The rate at which small firms in Nigeria fail and young graduates shy away from entrepreneurship practice call for reexamination of the entrepreneurship education curriculum and the framework for its implementation in tertiary institutions in Nigeria..

\subsection{Objectives of the Study}

The nucleus of this paper is to re-examine the entrepreneurship education curriculum and the framework for its implementation with a view to determine its effects on students' entrepreneurial development while the specific objectives of the paper are:

1. To determine whether the pedagogical methods for the entrepreneurship education in higher institution Nigeria is effective for developing entrepreneurial mindset of the students.

2. To find out the challenges hindering the implementation of entrepreneurship education curriculum in tertiary institutions in Nigeria.

3. To spot the limitations inherent in the current entrepreneurship curriculum in higher institutions in Nigeria that makes it unsuitable for development of entrepreneurship practice.

4. To find out factors that hinder graduates from entering into entrepreneurship practice after acquiring formal entrepreneurship education in Nigeria.

\subsubsection{Research Questions}

1. How effective is the pedagogical methods for the entrepreneurship education in higher institution in Nigeria in developing entrepreneurial mindset of students?

2. What are the challenges hindering the implementation of entrepreneurship education curriculum in tertiary institutions in Nigeria?

3. What are the limitations inherent in the current entrepreneurship curriculum in higher institutions in Nigeria that make it unsuitable for development of entrepreneurship practice?

4. What are the factors that hamper fresh graduates from entering into entrepreneurship practice after acquiring formal entrepreneurship education in Nigeria?

\subsubsection{Hypotheses for the Study}

$\mathrm{H}_{0}$ : The pedagogical methods for the entrepreneurship education in higher institution in Nigeria are not effective in developing the entrepreneurial mindsets of students.

$\mathrm{H}_{0}$ : The challenges hindering the implementation of entrepreneurship education in tertiary institutions in Nigeria include Poor implementation attitude, Poor entrepreneurship teaching techniques, Poor infrastructural facility for entrepreneurship education, Corruption, inadequate funding and incompetent teaching/training staff.

$\mathrm{H}_{0} \quad$ The current entrepreneurship curriculum in higher institutions in Nigeria is more theoretical and unsuitable for development of entrepreneurship practice.

$\mathrm{H}_{0} \quad$ Inability of the graduates to raise money to go into full entrepreneurship practices after graduation, unwillingness of youth of today to go into ventures that take long gestation period, value system in Nigeria which does not recognize hard work without any immediate monetary reward, desire of most youths of these days to earn income without working for it and desire to make it quick among the youths hamper fresh graduates from entering into entrepreneurship practice after acquiring formal entrepreneurship education in Nigeria.

\section{Conceptual Framework of the Study}

\subsection{Meaning of Entrepreneurship}

Entrepreneurship refers to the intention, creation or transformation of an organization resources (Bird \& Jelinek, 1989). Kuratko (2005) sees entrepreneurship as a dynamic process of vision, change and creation. It requires to be taught for the transfer of its skill and knowledge from an expert to someone else. It involves an application of energy and passion towards the creation of an enterprise and this includes: willingness to take calculated risks; team work; having creative skill to marshal needed resources; fundamental skill of building solid business plan; 
and finally, having the vision to recognize opportunity where others see chaos, contradiction, and confusion (Watkins-Marthys, 2009).

\subsubsection{Entrepreneurial Characteristics}

Entrepreneurial characteristics can be defined as specific personality traits that are typical of entrepreneurs, i.e. individuals owning and managing entrepreneurial ventures and engaged in entrepreneurial projects in various stages of development (Holienka, Holienkova. \& Gál. 2015). Entrepreneurs whether students, non-students, graduates, young or old possesses peculiar characteristics required for carrying out successful entrepreneurial ventures. These characteristics may differ depending on the researchers' interest. They includes, desire for achievement Clelland (1961) in Holienka1, Holienkova, and Gal (2015); Locus of control Rotter (1966), Risk taking propensity, Brockaus (1980) in Antoncic, Antoncic, Gantar, Hisrich, Marks, Bachkirov, Zhaoyang, Polzin, Borges, Coelho, \& Kakkonen, 2018). Other characteristics as identified by researchers such as Morrison (2001) in Amiri and Marimaei (2012) include: competitive, confidence, determination, humour, imperious, independence, intelligence, sense of self awareness, vivacious; cultural assimilation, moral values, religious, marginality and work ethics. These characteristics have become the focus of many researchers in recent times. Youths often have a special personality. They value the issue of strength, autonomy and independence as important in their desire to become entrepreneurs (Bhandari, 2006); perceive change as an opportunity to unleash their potentials and are willing to take moderate risk (Ajike, Nnorom, Akinlabi, Onyia \& Kwarbai, 2015) as well as have social skills and possess a balance intuition and thinking (Buttner \& Rosen, 1989 in Kyalo \& Kiganane 2014).

On the other hand, Mustafa, (2019) notes that family background, creativity, personal attributes, attitude, skills propel the interest of young graduates to go into entrepreneurship, Clelland (1961) in Holienka1, Holienkova, and Gal (2015) point towards achievement; Giacomin, Guyot, Janssen and Lohest (2007) found push factors such as desire for independence and pull factors such as profit objective and social status to influence younger people to venture into entrepreneurship. Sajjad, Shafi and Dad (2012) notes culture, perceived feasibility, desirability and experience as factors that influences would be entrepreneur's intention to start new business. It has been observed that peer influence equally play a part forming the entrepreneurial mindset of the young graduates. On the whole, these personality traits are all valuable but require some formal professional touch to make it more useful to the possessor. This is the sense behind the proposition for entrepreneurship education.

\subsubsection{Entrepreneurship Education and Entrepreneurship Education Curriculum}

Entrepreneurship education curriculum is the outlined framework for imparting entrepreneurship knowledge, skills and attitudes into students of tertiary institutions that would enable them become self reliant and manage their personal businesses after graduation. Entrepreneurship education is focused on developing youth with the passion and multiple skills. It aims to reduce the risk associated with entrepreneurship practice and guide the enterprise successfully through its initial stage to the maturity stage. Brown (2000) remarks that entrepreneurship education is designed to communicate and inculcate competencies, skills and values needed to recognize business opportunity, organize and start new business venture. Gorman, Hanlon and King (1997) see entrepreneurship education as an educational programme that is focused on impacting student with issues on entrepreneurship. Chukwudi and Nwosu (2018) identified entrepreneurship education as a major means of assisting youths and even adult to acquire desired skills and capacities to be self-reliant or self-employed, particularly to prepare them to be able to set up their own ventures and manage them profitably. Entrepreneurship education has passed through several development stages. Postigo and Tamborini (2007) reviewed and analyzed four lines of research that describe the details of this phenomenon in different outlines, these include:

i. The study of the impact that entrepreneurship education has on the students at the university level (Price \& Moure, 1993).

ii. The analysis over the pedagogic instruments and methodologies used to teach entrepreneurship education (Plashka \& Wlesch, 1990).

iii. The research related to the state of art entrepreneurship education (Vesper and Garter, 1997).

iv. Report on practical experience at different educational level (Mason, 2000).

Other studies have listed out what the content of good entrepreneurship education programme should be. These include; Leadership, Negotiation, Creative thinking, exposure to technology, Invention and Innovation (McMullan \& Long, 1987). Opportunity identification venture capital, idea generation, and protection tolerance ability, ability to tackle challenges of different entrepreneurship stages, personality traits, ability to write and communicate business plan, new venture development, ability to diagnose business performance, networking and mentorship, environment analysis, computer and simulation skills, case studies, film and videoing, and company analysis (Zeithamal \& Rich, 1987). Therefore, it is not out of place to state that entrepreneurship 
education builds the foundation for stable and successful entrepreneurship practice.

\subsubsection{Entrepreneurship and Entrepreneurship Education}

While entrepreneurship is a concept that involves mental activities such as creativity, innovations and parchedness, entrepreneurship education is designed to prepare student for engaging in a self-directed economic activities such as seeking opportunities, taking risk and have the tenacity to push an idea through reality combined with a special perspective that permeates entrepreneurship (Adenikpeku, 2004). To Garavan, Costine, and Hegarty (1995), entrepreneurship education is a series of activities which aims to enable an individual to assimilate and develop knowledge, skills, values and understanding that are not simply related to a narrow field of activity but which allow a broad range of problems to be defined, analyzed and solved. It focused on developing student with passion and skills needed to create inherently risky entrepreneurial enterprises and guide the enterprise successfully through its initial stage to the maturity stage. It communicates and inculcates the skills needed to recognize business venture (Brown, 2000). It aims is to help young people develop skills and attributes that allow them to innovate and identify, initiate and successful manage personal and work opportunities, including working for themselves (Walstad \& Jouriki, 1999).

Relating education to entrepreneurship studies by different scholars revealed that there are different perspectives and approaches that can be adopted (Clark, Davis, \& Harnish, 1984). The adoption of these approaches depends on the institutional decision and programme design. Aside formal setting, researchers are of the view that entrepreneurship can also be communicated through conferences, seminar, journal publications, workshop programmes and using the platform of research center (Adenipekan, 2004). Enhancement in the quality of entrepreneurship education is one of the areas that have developed relevant knowledge in our time. Evaluating the effect of education on entrepreneurship, a great deal of emphasis is placed on interaction between education and industry, expert of exchanges and the transfer of knowledge from educational establishment to business education either about or for entrepreneurship, helps in new business creation, development of entrepreneurial process and issues that have to do with theories and management of entrepreneurial ventures.

\subsubsection{Entrepreneurship Education and Entrepreneurial Development}

Generally, development is the cognitive state immediately prior to executing behaviour (Krueger, 2005). Thus an entrepreneurial development is concerned with the inclination of a person to start entrepreneurial activity in the future (Davidson, 1995). It is a key determinant of the action of raw ventures creation moderated by exogenous variables such as family background, position in one's family, parents, occupation, education and training. Bird and Jelinek (1998) identified perceived desirability and feasibility as two other critical antecedents of entrepreneurial development. Bird (1988) observes that intentionality is a state of mind that direct a person attention (experience and action) towards specific objectives (goal) or a path in order to achieve something (means). It emphasizes the reason or motivational factors identified which underline their actions. Researchers such as Shapero and Sokol (1982); Carsrud and Johnson (1988), looked at two broad factors i.e. individuals and environmental. An individual with either of entrepreneurial characteristics, abilities and perspective must find $\mathrm{him} / \mathrm{herself}$ in an environment conducive for entrepreneurial venturing. Researchers have identified education and training as one of these factors (Miettinen, 2006). And this has become more prominent among young people and graduates. It constitutes a key source of nascent entrepreneurs who will end up as either entrepreneurs or as owners of their own business or their family businesses. Thandi and Sharma (2003); Wilkinson (2005) confirmed that youths between the ages of 18-25 have the tendency of starting up their own business immediately after graduation or within five years after graduation. Apart from education, individuals who want to be entrepreneurs can also distinguish themselves from others by intentionally sourcing their own resources required for the success of the enterprise. Development towards a thing, therefore acts as a force that propels entrepreneurial actions and behaviour. It gives direction to some one's attention and determines experience one gets in life (Krueger, 2005).

\subsubsection{Influence of Entrepreneurship Education on Entrepreneurial Intentions}

Here, the paper looked at the relationship between entrepreneurship education and entrepreneurial intentions. Does entrepreneurship education influence the student intentions to start a new business? Intention according to Ajzen (1991) is generally recognized as a specific behaviour. Krueger, Reilly and Carsrud, (2000) remark that intention can be a single predictor for entrepreneurial behaviour, other researchers such as Simon and Shrader, (2012) also explored the relationship between entrepreneurship education and student's entrepreneurial developments. Their studies revealed that most of the entrepreneurial activities start from attitudinal behaviour exhibited by the prediction of entrepreneurial development. Under studying the relationship between entrepreneurship education and development is very significant so as to justify the introduction of entrepreneurship education in our higher institutions. Certain factor according to existing literature may relate to intentions and behaviour. On this note, Simon and Shrader (2012); Birth and Jelink (1988) are of the view that an 
entrepreneur(s) attitude and behaviour has a way of influencing the realization of his intentions. To expatiate this further, behaviour theorist are of the opinion that past behaviour and experience has a positive relationship with someone future intents. The study of Miettien (2006) threw more light on how student entrepreneurial development can easily be identified using the 2006 ICSE (the Indian certificate of secondary education), he compared the entrepreneurial activities and development of student in an international context.

\subsubsection{Entrepreneurship Education and Motivation for Entrepreneurship Practice}

Student(s) motivation for entrepreneurship practice may or may not relate to their entrepreneurship education. Several motivational factors exist among graduating student that could differently influence their intentions to start up a firm. Tanveer, Zafar, Shafique, Jhangir and Rizvi (2013) identified desire for independence, Job security, availability of capital for investment, successful entrepreneurial role models, market opportunity, earning, and challenging career as factors that influence graduates intentions to start up a firm. However, Ozaralli and Rivenburgh (2016) found that students hold a positive attitude towards entrepreneurship, but show a low level of entrepreneurial intention. The authors also confirm that there is a statistically significant relationship among personality attributes of optimism, innovativeness, risk-taking propensity and entrepreneurial intention. The reason behind this is because in most cases, students are pressurized by their instructors or programme policy or grant/fund availability (which emphasizes on student registration of their own business) to start up a business while still in school as an indication of their entrepreneurial development. This has created a challenge of not having a clear cut distinction between entrepreneurial education and students actual intentions to start up a business. Thandi and Sharma (2003) developed a conceptual framework to demonstrate the relationship between antecedents factors (entrepreneurship drivers) intervening variables or entrepreneurial education (entrepreneurial facilitators) and entrepreneurial intentions (Entrepreneurial actions or outcomes) among students. According to the authors, entrepreneurship education acts as intervening variables to someone's intention to start up entrepreneurship venture. But the concern of the present author is where the methods of delivering the entrepreneurship lectures are mostly theoretical and possibly training on producing some items without the practice of how to open a new business, learning to develop the tenacity in managing a business in term of resource management and control with an already established entrepreneur. Again where factor such as availability of startup capital is not possible, machine that are need for the business is beyond the financial capability of the student, what becomes of the intention of the student to venture into entrepreneurship practice after graduation?

\subsubsection{Relationship between Entrepreneurship Education and Economic Development}

Entrepreneurship education relate to economic development in number of ways, for instance in increasing unemployment and under employment all over the World and most especially in developing countries, entrepreneurship creates employment opportunities and as well as develop skills required for effective business management etc. Also given the need to equip the current and future workforce with the skills required by the new economy, attention has always been turned to entrepreneurship education. Entrepreneurship education is expected to provide additional skills, resources, and methodologies to graduates to further transform their ideas into visible and viable businesses after graduating from the university.

Hisrich, Peters and Dean (2008) hold that economic growth arises from increasing per capita output and income as well as initiating and constituting change in the structure of business and society. The authors note that many countries, rundown areas or communities have been energized through entrepreneurship programmes. In relating entrepreneurship education to economic growth and development (Dejardin, 2000) observed that an increase in the number of entrepreneurs leads to an increase in economic growth. Ahiauzu (2010) in supporting the above view points out that there is a positive relationship between entrepreneurship education and economic growth and development. Henderson (2007) concludes that entrepreneurship education will spur innovative ideas and add value through the commercialization of new products, the creation of new jobs, and the building of new firms. Entrepreneurship education is a catalyst for economic development and job creation in societies and it involves rebranding the education culture to the end of guaranteeing a comprehensive educational system reengineering arising from the obvious deficiencies of the existing educational system (Lee and Wong, 2005). In other words, entrepreneurship education provides a platform for graduates to transform opportunities to business ventures and to manage those ventures to become a medium for job creation for themselves and others which is a very vital aspect of economic development.

\section{Theoretical Framework of the Paper}

Theory is always considered simply from the academic perspective which should not be so. Theories help in the understanding of concepts, which may guide decisions and actions in a much better way than if no clear explanation were put forward. Theories have a fundamental influence in shaping judgment and action at every conceivable level (Amolo \& Migiro, 2014). The challenges that are faced as a result of differences in definitions 
may be related to the theories that need review. Such review is necessary for the opening up of a robust debate in contextualising the understanding of a concept (for instance entrepreneurship) from a scholarly perspective, as well as for policy platforms (Amolo \& Migiro, 2014). The theory of entrepreneurship education will be considered from teachability of entrepreneurial competency and learnability of entrepreneurial competency.

The theory of entrepreneurship education states that any reflection on the teachability and learnability of entrepreneurial expertise first demands an understanding of the teaching and learning subjects. The focus of teachability is on subjects who 'undertake' to impart the innovative/creative knowledge and skills of entrepreneurs (which helps to generate added value in an economy through change) on subject who are willing and have the capacity to learn. The other aspect is those subjects who are willing and are able learn and acquire the knowledge/skills which embodies the values of entrepreneurs and go on to become entrepreneurs. This is therefore the difference between the question of the teachability and learnability in entrepreneurship education.

Assuming there is an academic interest in the theme entrepreneurship, teaching and learning is based to a great extent on theories of the entrepreneur, his features, typical mistakes which he makes and his role in the economy and society. This group can be called 'those interested in (the theme) entrepreneurship'. If on the other hand the interest is of a practical nature, teaching and learning will concentrate on preparing the subjects for their own entrepreneurial career. Therefore this group can be called 'those interested in becoming entrepreneurs'. Therefore, the success of entrepreneurship education at building and directing the mindset of the young graduate to entrepreneurial practice more often is both in the hands of the teacher, learner and the teaching methods. On that note, theory has significance that affects the reality of issues upon which people act.

Social cognitive theory provides framework for understanding how people actively shape and are shaped by their environment. The theory envisions persons as agents and active contributors to the development of the circumstances that surround their lives (Bandura, 2018). In particular, the theory details the processes of observational learning and modeling, and the influence of self-efficacy on the production of behaviouur. Entrepreneurship education helps improve the cognition, constantly adjust the thoughts and actions of participants, and make the entrepreneurship practice more directional, coherent and meaningful. Therefore, this paper employs the theory of social cognition to examine how entrepreneurship education curriculum and the framework for its implementation in tertiary institutions can enhance learner(s) ability in developing the entrepreneurial mindset, which in turn affects entrepreneurial innovative awareness, innovative ability, and innovative personality in Nigeria. Since the entrepreneurial curriculum system lays the foundation for the overall improvement of students' entrepreneurial ability.

\section{Methodology of the Study}

The paper made use of participants from Alex Ekwueme University Ndufu Alike Ikwo, Akanu Ibiam federal Polytechnic, Unwana and Federal College of Agriculture Ishiagu, all in Ebonyi State. The combined population of the students and lecturers/facilitators involved in the study are twelve thousand eight hundred and seventy two (12872) (i.e. 12700 students and 172 lecturers/facilitates). Alex Ekwueme University Ndufu Alike Ikwo has four thousand students and fifty three lecturers/facilitators; Akanu Ibiam Federal Polytechnic has five thousand seven hundred students and seventy six lecturers/facilitators while Federal College of Agriculture Ishiagu has three thousand students and forty three lecturers/facilitators. From the twelve thousand seven hundred students and one hundred and seven two lecturers/facilitators a sample size of three hundred and eighty four of the population was determined using Cochran's equation for sample for proportions and for populations that are large. The sample size was apportioned proportionately between students and lecturers/facilitators and between the institutions, which gave three hundred and seventy nine to students and 5 to lecturers/facilitators and for the institutions, Alex Ekwueme University Ndufu Alike Ikwo has one hundred and nineteen (119) for students and two (2) for lecturers/facilitators; Akanu Ibiam Federal Polytechnic, Unwana has one hundred and seventy for students and two (2) for lecturers/facilitators while Federal College of Agriculture Ishiagu has ninety (90) for students and one (1) for lecturers/facilitators.

\section{Data Analysis and Test of Hypotheses}

\subsection{Data Analysis}

This section of the work focused on analysis of response of research participants on the subject matter. The analysis was based on mean score rating using data collected through the Likert five point scales weighted questionnaire. The rule is that mean scores below 3.00 will be rejected and therefore not acceptable. 
Table 1: Effectiveness of the pedagogical methods for the entrepreneurship education in developing entrepreneurial mindset of the students in tertiary institutions in Nigeria

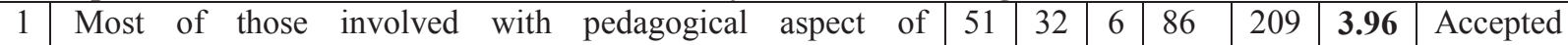
Entrepreneurship education are not competent to handle entrepreneurship subject.

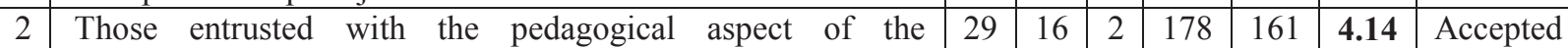
entrepreneurship education programme placed personal interests above the objective of the programme.

3 There is no effective monitoring of the implementation of the pedagogical aspect of the entrepreneurship education programme in higher institutions in Nigeria.

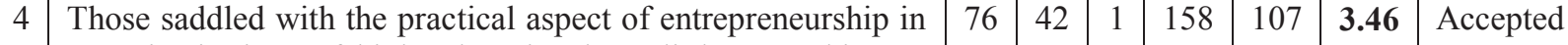
most institutions of higher learning have little or nothing to offer the students as take home knowledge from items of study.

5 The length of interaction between the lecturers/facilitators and students is too short for the students to gain the required knowledge to develop the required entrepreneurial mindset.

Source: Field Survey, 2020.

From the mean score rating table 4.1, (see appendix I) options 1, 2, 3, 4 and 5 were accepted. This indicates that most of the lecturers/facilitators involved with pedagogical aspect of Entrepreneurship education are not competent to handle entrepreneurship subject, they placed personal interests above the objective of the programme, no effective monitoring of the implementation of the pedagogical aspect of the entrepreneurship education programme in higher institutions in Nigeria by the authorities concerned, those saddled with the practical aspect of entrepreneurship in most institutions of higher learning have little or nothing to offer the students as take home knowledge from the items of study and the length of interaction between the lecturers/facilitators and students is too short for the students to gain the required knowledge to develop the required entrepreneurial mindset. The inference from the analysis of data from table 4.1 is that pedagogical methods for the entrepreneurship education in developing entrepreneurial mindset of the students in tertiary institutions in Nigeria are ineffective.

A one on one discussion with some students collaborates the outcome of the result of the analysis on table 4.1, that most of the lecturers/facilitators involved with pedagogical aspect of Entrepreneurship education are not competent, they placed personal interests above the objective of the programme, no effective monitoring of the implementation of the pedagogical aspect of the entrepreneurship education, those saddled with the practical aspect of entrepreneurship in most institutions of higher learning have little or nothing to offer the students and the short duration of time attached to programme affect the pedagogical aspect of the programme formed the main inference from the analysis.

Table 2: The challenges inherent in the implementation of entrepreneurship education in tertiary institutions in Nigeria

\begin{tabular}{|c|c|c|c|c|c|c|c|c|}
\hline 1 & $\begin{array}{l}\text { Poor implementation attitude to entrepreneurship education } \\
\text { curriculum in tertiary institutions in Nigeria }\end{array}$ & 33 & 92 & 2 & 137 & 120 & 3.57 & Accepted \\
\hline 2 & $\begin{array}{l}\text { Poor entrepreneurship teaching techniques in tertiary } \\
\text { institutions in Nigeria }\end{array}$ & 76 & 63 & 1 & 145 & 95 & 3.27 & Accepted \\
\hline 3 & $\begin{array}{l}\text { Poor infrastructural facility to aid entrepreneurship education } \\
\text { in tertiary institution }\end{array}$ & 45 & 61 & 2 & 147 & 131 & 3.69 & Accepted \\
\hline 4 & $\begin{array}{l}\text { Corruption which has become endemic within Nigerian } \\
\text { Society }\end{array}$ & 55 & 81 & 0 & 151 & 97 & 3.40 & Accepted \\
\hline 5 & $\begin{array}{l}\text { Inadequate funding for the entrepreneurship education in } \\
\text { Nigeria }\end{array}$ & 65 & 57 & 2 & 123 & 139 & 3.57 & Accepted \\
\hline
\end{tabular}

Source: Field Survey, 2020.

The mean score rating in table 4.2 (see appendix II), revealed that options 1, 2, 3, 4 and 5 were all accepted, which implies that poor implementation attitude to entrepreneurship education curriculum, poor entrepreneurship teaching techniques, poor infrastructural facility to aid entrepreneurship education, corruption which has become endemic within Nigerian Society and inadequate funding for the entrepreneurship education are the challenges inherent in the implementation of entrepreneurship education in tertiary institutions in Nigeria. These issues are serious challenge to the implementation of entrepreneurship education in tertiary institutions in Nigeria.

The conclusion from the analysis of data in table 4.2 show that poor implementation attitude to entrepreneurship education curriculum, poor entrepreneurship teaching techniques, poor infrastructural facility to 
aid entrepreneurship education, corruption which has become endemic within Nigerian Society and inadequate funding for the entrepreneurship education are the challenges inherent in the implementation of entrepreneurship education in tertiary institutions in Nigeria.

Table 3: Limitations in the entrepreneurship curriculum in higher institutions in Nigeria that makes it unsuitable for entrepreneurial practice development

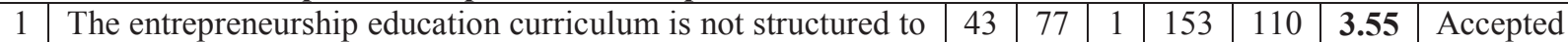
equip the students with the required skills that can make them succeed in competitive World of entrepreneurship practice.

2 The entrepreneurship education programme in most tertiary institutions is more theoretical oriented and lack adequate practical input.

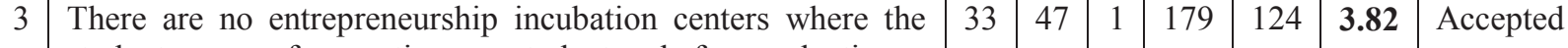
students can go for practice as a student and after graduation.

4 Lack/absence of a curricular guide to inform a pedagogical delivery system.

5 Absence of research support and linkages

Source: Field Survey, 2020.

The outcome of the mean score rating in table 4.3 (see appendix III), show that all the options were accepted. This uncovers the fact that entrepreneurship education curriculum is not structured to equip the students with the required skills that can make them succeed in competitive World of entrepreneurship practice, entrepreneurship education programme in most tertiary institutions is more theoretical oriented and lack adequate practical input, no entrepreneurship incubation centers where the students can go for practice as a student and after graduation, lack/absence of a curricular guide to inform a pedagogical delivery system and absence of research support and linkages.

The deduction from the analysis from table 4.3 reveals that entrepreneurship education curriculum is not structured to equip the students with the required skills, entrepreneurship education programme in most tertiary institutions is more theoretical oriented and lack adequate practical input, no entrepreneurship incubation centers where the students can go for practice and lack/absence of a curricular guide to inform a pedagogical delivery system and absence of research support and linkages are the limitations in the entrepreneurship curriculum in higher institutions in Nigeria that makes it unsuitable for entrepreneurial practice development.

Table 4: Other factors hindering entrepreneurship education as a mechanism for developing youth entrepreneurial intention in Nigeria

\begin{tabular}{l|ll|l|l|l|l|l|l|l|}
1 & The inability of the graduates to raise money to go into full & 61 & 45 & 0 & 161 & 117 & $\mathbf{3 . 5 9}$ & Accepted
\end{tabular} entrepreneurship practices after graduation is a huge hindrance.

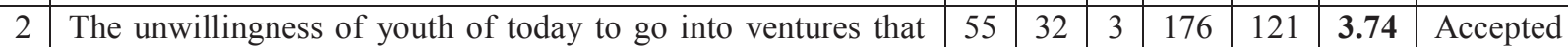
take long gestation period.

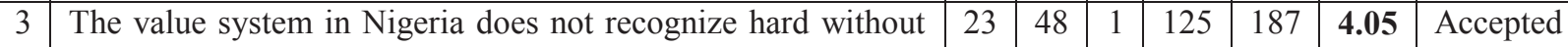
any immediate monetary reward.

\begin{tabular}{l|ll|l|l|l|l|l|l} 
& The desire of most youths of these days to earn income & 34 & 52 & 3 & 155 & 140 & $\mathbf{3 . 8 2}$ & Accepted
\end{tabular} without working for it.

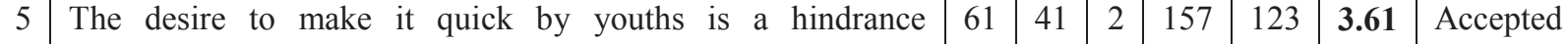
entrepreneurship education and desire for entrepreneurial development

Source: Field Survey, 2020.

The outcome of the mean score rating in table 4.4 (see appendix III), show that all the options were accepted. This unearth the fact that inability of the graduates to raise money to go into full entrepreneurship practices after graduation is a huge hindrance to entrepreneurship education as a mechanism for developing youth entrepreneurial intention in Nigeria, unwillingness of youth of today to go into ventures that take long gestation period is a hindrance to entrepreneurship education as a mechanism for developing youth entrepreneurial intention in Nigeria, value system in Nigeria which does not recognize hard without any immediate monetary reward is a hindrance to entrepreneurship education as a mechanism for developing youth entrepreneurial intention in Nigeria, desire to make it quick by youths is a hindrance entrepreneurship education and desire for entrepreneurial development.

The inference therefore is that factors such as inability of the graduates to raise money to go into full entrepreneurship practices after graduation, unwillingness of youth of today to go into ventures that take long gestation period, value system of Nigeria which does not recognize hard without any immediate monetary reward and desire to make it quick by youths are hindering entrepreneurship education as a mechanism for 
developing youth entrepreneurial intention in Nigeria.

\subsubsection{Test of Hypotheses}

The data generated from the questionnaire distributed to the participants were further subjected to hypothetical test using T-Distribution test statistic. The results are discussed below.

Statement of Hypothesis I

$\mathrm{H}_{1}$ : The pedagogical methods for the entrepreneurship education in higher institution is effective in developing the entrepreneurial mindsets of the students in tertiary institutions in Nigeria

Test of hypothesis I

Test Statistic: T-Distribution Analysis was used to test the validity of the postulation.

Level of Significant: $\alpha=0.05$

Rejection Rule: Reject $H_{0}$ if $t_{c a l}>t_{t a b}$, otherwise accept or Reject $H_{0}$ if Sig - value $<\alpha=0.05$

\begin{tabular}{|c|c|c|c|c|c|c|}
\hline \multicolumn{7}{|c|}{$\begin{array}{c}\text { SPSS Output for T-Distribution Table } 1 \\
\text { Independent Samples Test }\end{array}$} \\
\hline & \multicolumn{2}{|c|}{$\begin{array}{c}\text { Levene's Test for Equality } \\
\text { of Variances }\end{array}$} & \multicolumn{4}{|c|}{ t-test for Equality of Means } \\
\hline & $\mathrm{F}$ & Sig. & $\mathrm{t}$ & Df & $\begin{array}{l}\text { Sig. }(2- \\
\text { tailed) }\end{array}$ & $\begin{array}{c}\text { Mean } \\
\text { Difference }\end{array}$ \\
\hline $\begin{array}{ll}\text { HYPOTH } & \text { Equal variances } \\
1 & \text { assumed } \\
& \begin{array}{l}\text { Equal variances not } \\
\text { assumed }\end{array}\end{array}$ & .220 & .651 & $\begin{array}{l}1.100 \\
1.100\end{array}$ & $\begin{array}{r}8 \\
7.374\end{array}$ & $\begin{array}{l}.303 \\
.306\end{array}$ & $\begin{array}{l}14.40000 \\
14.40000\end{array}$ \\
\hline
\end{tabular}

Source: Data Analysis output, 2020.

Discussion of Result

At $\alpha=0.05$ level of Significance, $P-$ value $=0.303>\alpha=0.05$.

Based on the result from SPSS output for T-Distribution table 4.1, there is no sufficient evidence to reject the null hypothesis and accept the alternative since $P-$ value $=0.303>\alpha=0.05$. Therefore, we conclude that the pedagogical method for the entrepreneurship education in higher institution is not effective in developing the entrepreneurial mindsets of the students in tertiary institutions in Nigeria

Statement Test of Hypothesis II

$\mathrm{H}_{1}$ : There are no challenges hindering the implementation of entrepreneurship education in tertiary institutions in Nigeria.

Test of Hypothesis II

Test Statistic: T-Distribution Analysis was used to test the validity of the postulation.

Level of Significant: $\alpha=0.05$

Rejection Rule: Reject $H_{0}$ if $t_{c a l}>t_{t a b}$, otherwise accept or Reject $H_{0}$ if Sig - value $<\alpha=0.05$

\begin{tabular}{|c|c|c|c|c|}
\hline \multicolumn{5}{|c|}{$\begin{array}{c}\text { SPSS Output for T-Distribution Table } 2 \\
\text { Independent Samples Test }\end{array}$} \\
\hline & $\begin{array}{c}\text { Levene's Test for Equality } \\
\text { of Variances }\end{array}$ & \multicolumn{3}{|c|}{ t-test for Equality of Means } \\
\hline & $\mathrm{F}$ & Df & $\begin{array}{l}\text { Sig. }(2- \\
\text { tailed) }\end{array}$ & $\begin{array}{c}\text { Mean } \\
\text { Difference }\end{array}$ \\
\hline $\begin{aligned} \text { HYPOTH2 } & \text { Equal variances assumed } \\
& \text { Equal variances not assumed }\end{aligned}$ & .000 & $\begin{array}{r}8 \\
7.903\end{array}$ & $\begin{array}{l}.151 \\
.151\end{array}$ & $\begin{array}{l}-16.00000 \\
-16.00000\end{array}$ \\
\hline
\end{tabular}

Source: Data Analysis output, 2020.

Discussion of Result

Given $\alpha=0.05$ level of Significance, $P-$ value $=0.151>\alpha=0.05$, This SPSS output T-Distribution table 4.2 result is not sufficient to reject the null hypothesis and accept the alternative since $P$-value $=0.303>\alpha=0.05$. Therefore, we deduce that the challenges hindering the implementation of entrepreneurship education in tertiary institutions in Nigeria include Poor implementation attitude, Poor entrepreneurship teaching techniques, Poor infrastructural facility for entrepreneurship education, corruption, 
inadequate funding and Incompetent teaching/training staff.

Statement of Hypothesis III

$\mathrm{H}_{1} \quad$ The current entrepreneurship curriculum in higher institutions in Nigeria is practical oriented and suitable for development of entrepreneurship practice

Test of Hypothesis III

Test Statistic: T-Distribution Analysis was used to test the validity of the postulation.

Level of Significant: $\alpha=0.05$

Rejection Rule: Reject $H_{0}$ if $t_{c a l}>t_{t a b}$, otherwise accept or Reject $H_{0}$ if Sig - value $<\alpha=0.05$

\begin{tabular}{|c|c|c|c|c|c|c|c|}
\hline \multicolumn{8}{|c|}{$\begin{array}{c}\text { SPSS Output for T-Distribution Table } 3 \\
\text { Independent Samples Test }\end{array}$} \\
\hline & \multicolumn{2}{|c|}{$\begin{array}{c}\text { Levene's Test for } \\
\text { Equality of } \\
\text { Variances } \\
\end{array}$} & \multicolumn{5}{|c|}{ t-test for Equality of Means } \\
\hline & $\mathrm{F}$ & Sig. & $\mathrm{T}$ & Df & $\begin{array}{l}\text { Sig. (2- } \\
\text { tailed) }\end{array}$ & $\begin{array}{c}\text { Mean } \\
\text { Difference }\end{array}$ & $\begin{array}{l}\text { Std. Error } \\
\text { Difference }\end{array}$ \\
\hline $\begin{array}{ll}\text { HYPOT } & \text { Equal variances } \\
\text { H3 } & \text { assumed } \\
& \text { Equal variances } \\
& \text { not assumed }\end{array}$ & .002 & .964 & $\begin{array}{l}-2.153 \\
-2.153\end{array}$ & $\begin{array}{r}8 \\
7.995\end{array}$ & $\begin{array}{l}.064 \\
.064\end{array}$ & $\begin{array}{l}-19.40000 \\
-19.40000\end{array}$ & $\begin{array}{l}9.01110 \\
9.01110\end{array}$ \\
\hline
\end{tabular}

Source: Data Analysis output, 2020.

Discussion of Result

Agreed, $\alpha=0.05$ level of Significance, $P-$ value $=0.151>\alpha=0.05$, The result from SPSS output TDistribution table 4.3 above does not give sufficient evidence to reject the null hypothesis and accept the alternative since $P$-value $=0.064>\alpha=0.05$ at 2-tail test. Therefore, we infer that the current entrepreneurship curriculum in higher institutions in Nigeria is more theoretical and unsuitable for development of entrepreneurship practice. Infer

Statement of Hypothesis IV

$\mathrm{H}_{1} \quad$ There are no factors hindering entrepreneurship education as a mechanism for developing student's entrepreneurial skill.

Test of Hypothesis IV

Test Statistic: T-Distribution Analysis was used to test the validity of the postulation.

Level of Significant: $\alpha=0.05$

Rejection Rule: Reject $H_{0}$ if $t_{c a l}>t_{\text {tab }}$, otherwise accept or Reject $H_{0}$ if Sig - value $<\alpha=0.05$

\begin{tabular}{|c|c|c|c|c|c|c|}
\hline \multicolumn{7}{|c|}{$\begin{array}{c}\text { SPSS Output for T-Distribution Table } 4 \\
\text { Independent Samples Test }\end{array}$} \\
\hline & \multicolumn{2}{|c|}{$\begin{array}{c}\text { Levene's Test for Equality of } \\
\text { Variances }\end{array}$} & \multicolumn{4}{|c|}{ t-test for Equality of Means } \\
\hline & $\mathrm{F}$ & Sig. & $\mathrm{t}$ & $\mathrm{df}$ & $\begin{array}{l}\text { Sig. }(2- \\
\text { tailed })\end{array}$ & $\begin{array}{c}\text { Mean } \\
\text { Difference }\end{array}$ \\
\hline $\begin{array}{ll}\text { HYPOTH } & \text { Equal variances } \\
4 & \text { assumed } \\
& \text { Equal variances } \\
& \text { not assumed }\end{array}$ & 7.987 & .022 & $\begin{array}{l}.378 \\
.378\end{array}$ & $\begin{array}{r}8 \\
5.497\end{array}$ & $\begin{array}{l}.715 \\
.720\end{array}$ & $\begin{array}{l}3.20000 \\
3.20000\end{array}$ \\
\hline
\end{tabular}

Source: Data Analysis output, 2020.

Discussion of Result

Based on the result of the data analyzed in SPSS output T-Distribution table 4.4, there is no sufficient evidence to reject the null hypothesis and accept the alternative since $P-$ value $=0.715>\alpha=0.05$. Therefore, we conclude that factors such as inability of the graduates to raise money to go into full entrepreneurship practices, 
unwillingness of youth of today to go into ventures that take long gestation period, value system in Nigeria does not recognize hard without any immediate monetary reward, desire of most youths of these days to earn income without working for it and desire to make it quick among the youths are hindering entrepreneurship education as a mechanism for developing student's entrepreneurial skill.

\section{Summary of Major Findings}

It was found that the pedagogical method for the entrepreneurship education in tertiary institution is not effective in developing the entrepreneurial mindsets of the students in tertiary institutions in Nigeria

The study discovered that the challenges hindering the implementation of entrepreneurship education in tertiary institutions in Nigeria include poor implementation attitude, poor entrepreneurship teaching techniques, poor infrastructural facility for entrepreneurship education, corruption, inadequate funding, incompetent teaching/training staff and most student's indifference to learning entrepreneurship as a subject.

The study exposed that the current entrepreneurship curriculum in higher institutions in Nigeria is more theoretical and unsuitable for development of entrepreneurship practice.

The study further revealed that factors such as inability of the graduates to raise money to go into full entrepreneurship practices, unwillingness of youth of today to go into ventures that take long gestation period, value system in Nigeria which does not recognize hard without any immediate monetary reward, desire of most youths of these days to earn income without working for it and desire to make it quick among the youths are hindering entrepreneurship education as a mechanism for developing student's entrepreneurial skill

\section{Discussion of Major Findings}

This section of the paper focuses on discussing the findings from data analysis and test of hypotheses to enable the author make reasonable conclusion/recommendations that can help the teaching of entrepreneurship in tertiary institutions in Nigeria.

The end result of the data analyzed on table 4.1 above show that the pedagogical method for the entrepreneurship education in tertiary institution is not effective in developing the entrepreneurial mindsets of the students in tertiary institutions in Nigeria. The result of test of hypothesis one conducted at $\alpha=0.05$ level of Significance, agree with this result that the pedagogical method for the entrepreneurship education in tertiary institution is not effective in developing the entrepreneurial mindsets of the students in tertiary institutions in Nigeria.

This outcome takes us back to the view expressed by Kuratko (2014) that the relevant question is not "can entrepreneurship be taught "but rather "what should be taught and how should it be taught?" In the case of Nigeria, the question of what should be taught is not the problem but how it should be taught. A closer examination of the individual lecturers/facilitators handling entrepreneurship subjects in classes shows that it will be difficult to achieve the objective of developing the entrepreneurial mindset of the students to venture into entrepreneurship practice after graduation. Again, teaching of entrepreneurship is less connected with the real entrepreneurial activity and is not focused on making the students get near entrepreneurial experience in the form of business plan preparation, case studies, group projects and interactions with entrepreneurs. The courses about entrepreneurship are taught in a traditional manner through lectures and text books.

Result of the data analyzed on table 4.2 above (see appendix 11) prove that the challenges hindering the implementation of entrepreneurship education in tertiary institutions in Nigeria include poor implementation attitude, poor entrepreneurship teaching techniques, poor infrastructural facility for entrepreneurship education, corruption, inadequate funding, incompetent teaching/training staff and indifference of most students to learning entrepreneurship as a subject. The outcome of the T-Distribution test conducted at $\alpha=0.05$ level of Significance corroborates the result above and reveals that poor implementation attitude, poor entrepreneurship teaching techniques, poor infrastructural facility for entrepreneurship education, corruption, inadequate funding, incompetent teaching/training staff and indifference of most students to learning entrepreneurship are part of the challenges hindering entrepreneurship education in Nigeria.

This result is tandem with the surmise of Ogbiji (2018); Olorundare and Kayode (2014); Adenike (2016); Chinonye and Akinbode (2014) that entrepreneurship education in Nigerian Universities lacked adequate implementation in the area of teachers, in terms of number and competencies, the students not being adequately exposed to professionals and industries outside their school setting, the funding and logistics for practices not adequately provided. Okebukola, (2004) and Onyeachno (2008) lay credence to this result and observed that poor curriculum implementation which has been a common phenomenon in the Nigerian education landscape which has prevented the realization of the objectives of many specialized education programme in the past, is a apparently the bane of entrepreneurship education among tertiary educational institutions in Nigeria. To be more explicit, Onyeachu (2008) asserts that no matter how well designed, planned and documented the curriculum of any subject is planned; the core issue of utmost importance is the implementation modalities.

Further, Proshare (2016) maintains that education infrastructure in Nigerian limits the effectiveness of 
entrepreneurship education in universities, while Undie and Bassey (2012) note that laboratories, workshops and facilities are in poor state in many Nigerian universities. They posit that infrastructural decay and obsolescence of equipment in the face of students' population explosion and shortage of academic staff among others pose serious challenges to entrepreneurship education in Nigerian tertiary institutions.

Amadi. and Eze, (2019) remark that Shortage of qualified lectures, inadequate facilities, inadequate teaching techniques, poor funding and lack of government support hinders the effective implementation of entrepreneurship education in tertiary institutions in Rivers State.

The corollary of data analysis on table 4.3 (see appendix 111) demonstrate that the current entrepreneurship curriculum in higher institutions in Nigeria is more theoretical and unsuitable for development of entrepreneurship practice. The hypothetical test at $\alpha=0.05$ level of Significance upheld this result and agree that current entrepreneurship curriculum in higher institutions in Nigeria is more theoretical and unsuitable for development of entrepreneurship practice.

The result agrees with Ifedili and Ofoegbu, (2011) that the current theoretical methods with emphasis on writing of business plan in groups of about 10-15 students is flawed. Zraa, Kavanagh and Hartle (2011) note that for the needed interaction among learners, the use of practical-oriented teaching methods as opposed to theoretic issues should be preferred if the objective of business-oriented education is to prepare students/trainees/graduates for the world of work. Tomczyk, and Vacek (2016) sanctioned the above views by asserting that Entrepreneurship education cannot be based mainly on lectures, presentations and other traditional tools. No amount of book based learning on its own will allow the student to progress in this field of entrepreneurship practice. They maintained that to acquire practical skills, companies established by students should constitute an important part of entrepreneurship in education.

The inference from data analysis on table 4.4 and the follow up test of hypothesis agreed that factors such as inability of graduates to raise money to go into full entrepreneurship practices, unwillingness of youth of today to go into ventures that take long gestation period, value system in Nigeria which does not recognize hard work without immediate monetary reward, desire of most youths of these days to earn income without working for it and desire to make it quick among the youths are hindering entrepreneurship education as a mechanism for developing student's entrepreneurial skill.

A one on one discussion with some students of the institutions under study gave credence to the above points. For instance, one of the students interviewed queried, "why should I waste my time, energy and money on doing entrepreneurship when it obvious I do not have the money to invest in any business of my choice. While another, made it clear that he is not ready to invest his money in any opportunity that will not give him immediate monetary rewards.

\section{Conclusions}

Conclusively, it is important to emphasize here as depicted in the results from the analyzed data and supported by the hypothetical tests, that the pedagogical methods for the entrepreneurship education in tertiary institutions in Nigeria is not effective in developing the entrepreneurial mindsets of the students.

The level of knowledge and experience possessed by the individual lecturers/facilitators handling entrepreneurship subjects in class shows that it will be difficult to achieve the objective of developing the entrepreneurial mindset of the students to venture into entrepreneurship practice after graduation.

Again, teaching of entrepreneurship is less connected with the real entrepreneurial activity and is not focused on making the students get near entrepreneurial experience in the form of business plan preparation, company/business formation, case studies, group projects and interactions with entrepreneurs. The courses about entrepreneurship are taught in a traditional manner through lectures and text books which does not offer the student the opportunity to acquire practical knowledge.

The implementation of entrepreneurship education in tertiary institutions in Nigeria is challenged and hindered by poor policy implementation attitude, poor infrastructural facility, corruption, inadequate funding, incompetent teaching/training staff and indifference of most students to learning entrepreneurship as a subject.

Again, current entrepreneurship curriculum in higher institutions in Nigeria is more theoretical and unsuitable for development of entrepreneurship practice. Entrepreneurship education cannot be based mainly on lectures, presentations and other traditional tools. No amount of book based learning on its own will allow the student to progress in the actual field of entrepreneurship practice.

Finally, factors such as inability of graduates to raise money to go into full entrepreneurship practices, unwillingness of youth of today to go into ventures that take long gestation period, value system in Nigeria which does not recognize hard work without immediate monetary reward, desire of most youths of these days to earn income without working for it and desire to make it quick among the youths equally hinder entrepreneurship education as a mechanism for developing student's entrepreneurial skill. The issues as enumerated above remain the focus of this paper as well as to the fact that entrepreneurship education as portrayed through social cognition theory, helps improve the cognition, constantly adjust the thoughts and 
actions of participants, and make the entrepreneurship practice more directional, coherent and meaningful.

\section{Recommendations}

Given the issues raised above, the following recommendations were made: The pedagogical methods for entrepreneurship education in tertiary institutions in Nigeria should include teaching methods outside of the traditional teaching format combined with training on how to produce some items like soap, wine, cosmetic products etc, i.e. the pedagogical methods should include School-based enterprises where students identify potential business, plan, create and operate small business by using the school as mini-incubators.

Opportunity should be created for an experienced and a successful entrepreneur to visit the incubation center to interact with students as a way of exposing them to actual practice. Thus creating an environment in which students learn through experience and help connect them with the real entrepreneurial activity which as well make them get near entrepreneurial experience in the form of business plan preparation, company/business formation, case studies, group projects and interactions with entrepreneurs. This helps to develop the entrepreneurial mindset of the students before graduation.

Subsequently, significant changes are required in the way teachers themselves are educated. Research has shown that the core skills and values linked to entrepreneurship education should be a priority in initial teacher education programmes. Number of lecturers/facilitators interviewed says that they would like to receive some further training on creativity. Some lecturers also remarked that educational and school cultures do not fully support them in fostering creative and innovative approaches to learning. Therefore lecturers/facilitators should be given opportunity to explore new approaches and a culture that encourages experimentation and allows for failure. Again, development of the entrepreneurship key competence is not simply a question of knowledge acquisition. Entrepreneurship education is about developing the ability to act in an entrepreneurial manner, attitude and behaviours are perhaps more important than knowledge about how to run a business. Entrepreneurship education means developing a culture which is through, for and about entrepreneurship. Such competencies are best acquired through people-led enquiry and discovery that enable students to turn ideas into action. They are difficult to teach through traditional teaching and learning practices in which the learner tends to be more or less passive recipient. They require active, learner-centred pedagogies and learning activities that use practical learning opportunities from the real world.

Teachers' attitudes toward the entrepreneurship subject and their perceptions about their capacity to successfully teach that subject is the first step in improving a positive attitude and strong self-efficacy among teachers. Where the teacher/lecturer/facilitator lacked the positive attitude, strong self efficacy and capacity, achieving the objective of entrepreneurship education becomes a mirage. Therefore, the teaching of entrepreneurship in tertiary institutions should not be all comers affair as currently observed in some of the institutions studied. Rather those with requisite background knowledge and experience in relevant areas should be allowed to handle both the theoretical and practical aspect. The allocation of entrepreneurship courses should not be used to settle loyalists or to those whose only objective is to make extra money from the students as was also observed in some of the institutions studied. Positive attitude, strong self efficacy and capacity in teaching entrepreneurship subjects should be the hallmark of the teachers given opportunity to teach such courses. Let those who possesses the competence in teaching be given the opportunity to teach entrepreneurship courses.

Over the years, Nigeria has built a reputation for poor attitude to policy implementation generally and entrepreneurship education policy is not an exception. This poor attitude stems from high level corruption which involves embezzlement, misappropriation of public fund which are meant to implement one policy or the other; over inflation of the cost of public contracts and even outright diversion of public fund to personal accounts. These in turn affect effective monitoring and control of public policy implementation because the fund has been shared among the policy initiators, implementers, controllers and monitoring teams. The problem of corruption has become so endemic that even in the various institutions, money are extorted from students using all sorts of avenue right from the authorities of the institution to the lecturers/facilitators. Then who will bail the cat. To achieve the objective of entrepreneurship education in Nigeria, people of proven integrity, should be employed to man key position of authority that will help in implementation of policy right from initiation, implementation, control and monitoring. People with questionable character should never be placed in positions that ensure effective monitoring and control in entrepreneurship education policy implementation.

Adequate facilities such as building of entrepreneurship centered with well equipped classroom and instructional material to facilitate the smooth teaching and learning of entrepreneurship in our tertiary institutions should be provided; there is need for substantial funds for teachings in practical terms for entrepreneurship; for financing start ups of fresh graduates and expansion of business ventures in order to produce successful entrepreneurs. Opportunities should be provided for graduates to raise funds to enable them start up and expand their business enterprise in a manner that will be momentous to them. This could be through bursary awards and in school assistance to enable students with entrepreneurship mindset to acquire savings before they are out of school or through grants made to them on graduation; research has shown that the indifference exhibited by most 
students towards learning entrepreneurship as a subject is as result of how the course was presented to them by the teacher teaching the course and the inability to raise start up funds after graduation to start business of their own. Therefore, it is important to make the learning of entrepreneurship more interesting by ensuring that graduates develop crucial life skills that will serve them well beyond the classroom walls and government should establish an agency with responsibility to give grants to students after graduation as startup capital to enable such graduates to start their business and guide them in managing it until such a time they can stand on their own.

To make the entrepreneurship education in higher institutions in Nigeria more suitable for development of entrepreneurship practice, there is need to review the current entrepreneurship education curriculum. The curriculum should be structured to inculcate in the undergraduate students/learners practical skills on idea generation in the environment, turning identified ideas to viable business opportunities, promoting and managing established businesses and acceptable global business ethics as well as rudiments for preparation of a business plan, business management skills, etc; equip the students with entrepreneurial skills, which are applicable directly to work, by structuring entrepreneurship education curriculum to provide education and training that enable individuals to involve directly in the entrepreneurial process, such as industrial training; structure entrepreneurship education curriculum to prepare students to act as entrepreneur; facilitate experiments by trying entrepreneurship out in a controlled environment, for instance through business simulation or role playing.

As earlier recommended, bursary awards and in school assistance that can enable students with entrepreneurship mindset to acquire savings before graduation or through grants made to them on graduation should be instituted; also government should establish an agency with responsibility to give grants to students after graduation as startup capital to enable such graduates start their business after graduation and guide them in managing it until such a time they can stand on their own. Students should be made to understand that starting a business requires a lot of mental alertness, no business starts on a cozy platter; business at the start is rough but one must have the requisite mental preparedness to stay on the business bearing in mind that "Nothing good comes easy in life". They should be taught that patience is the key and endurance is a big factor. On the long run, the hustle will pay off and the business will grow. The value system in Nigeria should be structured to recognize hard work while the desire to earn income without working for it or to make it quick among the youths must be discouraged. People who made their wealth through questionable means should be brought to book to serve as deterrent to students aiming at making it quick without working for it.

\section{References}

Adenike, A.A. (2016). Challenges of entrepreneurial education in Nigerian universities: Towards a repositioning for impact. Journal of Education \& Social Research, 6(1), 208-214.

Adenipekun, O. (2004). "Unemployment: Varsities and Entrepreneurial courses to Curriculum" Lagos: the Guardian.

Ahamefule, U. M. (1991). Entrepreneurial Development in Nigeria. Port Harcourt Nigeria: New Age Educational Publishing Company Ltd.

Ajike, E. O., Nnorom. G. K., Akinlabi, B. H., Onyia, V. A. \& Kwarbai, J. D. (January, 2015). "Entrepreneurship Education and Entrepreneurial Intentions: the Role of Theory of Planned Behaviour". .International Journal of Advanced Research in Social Engineering and Development Strategies ISSN Hard Print: 23158379 ISSN Online: 2354-161X

Ajzen, I. (1991). "The theory of planned behavior". Organisational Behaviour and Human Decision Processes, 50, 179-211.

Amadi, E. A. \& Eze, A. S. (April-June, 2019). "Factors Influencing the Implementation of Entrepreneurship Education in Tertiary Institutions in Rivers State", International Journal of Innovative Social \& Science Education Research 7(2):22-36,

Amolo, J. \& Migiro, S. O. (October, 2014). Entrepreneurship complexity: Salient features of entrepreneurship, 8(19), 832-841. https://doi.org/10.5897/AJBM2014.7442

Bandura, A. (2018). "Toward a Psychology of Human Agency: Pathways and Reflections". Perspectives Psychology Science. 13, 130-136. doi: 10.1177/1745691617699280

Bhandari, N.C. (September, 2006). "Intention for Entrepreneurship among students in India". The journal of Entrepreneurship 15(2),169-179.

Bird, B. (1988). "Implementing Entrepreneurial Ideas: The case for Intention", Entrepreneurship: Theory and Practice, 17(1), 11-20.

Bird, B. J. \& Jelinek, M. (1989). "The Operation of Entrepreneurial Intentions". Entrepreneurship Theory and Practice (ETP), DOI:10.1177/104225878801300205

Brockhaus, R. H. (1980). "Risk Taking Propensity of Entrepreneurs". Academy of Management, in Antoncic, J. A., Antoncic, B., Gantar, M., Hisrich, R.D., Marks, L. J., Bachkirov, A. A. Zhaoyang, L., Polzin, P., Borges, J. L., Coelho, A. \& Kakkonen, M. (March, 2018). "Risk-Taking Propensity and Entrepreneurship: The Role of Power Distance". Journal of Enterprising Culture (JEC), 26(01), 1-26, DOI: 
10.1142/S0218495818500012.

Brown, C. (2000) "Entrepreneurial Education, Teaching Guide" Kansas city M.O Kauffman centre for entrepreneurial leadership clearing house on Entrepreneurship Education PP 1 - 13.

Buttner, E. H, \& Rosen, B. (1989). "Funding New Business Ventures: Are Decision Makers Biased Against Women?", in Kyalo, T. N \& Kiganane, L. M. (June 2014). "Challenges Facing Women Entrepreneurs in Africa -A Case of Kenyan Women Entrepreneurs". International Journal of Advances in Management, Economics and Entrepreneurship, 1(2),01-08, ISSN: 2349-4468.

Carsrud, A. L. \& Johnson, R. W. (1988), "Entrepreneurship: A Social Psychology Perspective”. Working Paper, USC Entrepreneur Program, University of Southern California, Los Angeles

Chinonye, L.M. \& Akinbode, M.O. (2014). Entrepreneurship Curriculum and Pedagogical Challenges in Captivating Students' Interest towards Entrepreneurship Education. Research Journal of Economic Business Studies (RJEBS), vol. 4, no. 1.

Chukwudi, J. H. \& Nwosu, J. C. (October, 2018). "Entrepreneurship Education and the Challenges of Graduate Employability in Nigeria". International Journal of Innovation Management, 9(5):189-193, DOI: 10.18178/ijimt.2018.9.5.812

Clark, R. W., Davis, C. H. \& Harnish, V. C. (1984). "Do courses in entrepreneurship aid in new venture creation?" Journal of Small Business Management, 22(2), 26-31.

Davidsson, P. (1995)" Determinants of entrepreneurial intentions", Working Paper 1. Jonkoping: Jonkoping International Business School.

Dejardin, M. (2000). Entrepreneurship and Economic Growth: An Obvious Conjnction?. Belgium: Faculty of Economics and Social Sciences, University of Namur Publications

Durosaro, D. O. (2000). Resource Allocations and Utilization for University Education in Nigeria: Trends and Issue. Ilorin: Haytee Press.

Garavan, T. N. \& O'Cinneide, B. (1995).” Entrepreneurship education and training programmes: A review and evaluation-Part 1". Journal of European Industrial Training, 18 (8), 3-12.

Gartner, W. \& Vesper, K. H. (May, 1994). "Experiments in entrepreneurship education: Successes and failures". Journal of Business Venturing 9(3):179-187.

Giacomin, O., Guyot, J. L., Janssen, F. \& Lohest, O. (2007). "Novice Creators: Personal Identity and Push-Pull Dynamics", CRECIS Working Paper 07/2007, Centre for Research in Change, Innovation and Strategy, Louvain School of Management, downloadable through https://dial.uclouvain.be.

Gorman, G., Hanlon, D., \& King, W. (1997). "Some Research Perspectives on Entrepreneurship Education, Enterprise Education and Education for Small Business Management: A Ten-year Literature Review". International Small Business Journal, 15(3), 56-77.

Henderson, J. (2007). "Building the Rural Economy with High - Growth Entrepreneurs". Economic Review, 87 (3), $45-70$.

Hisrich, R. D., Peter, P. \& Dean, A. S. (2008). Entrepreneurship 7thEdition. Boston: McGraw-Hill/Irwin

Holienka, M. Holienkova, J. \& Gál, P. (2015). "Entrepreneurial Characteristics of Students in Different Fields of Study: A View from Entrepreneurship Education Perspective", Acta Universitatis Agriculturae Et Silviculturae Mendelianae Brunensis, 63(6) http://dx.doi.org/10.11118/actaun201563061879

Ifedili, C. and Ofoegbu, F. (2011). "Managing Entrepreneurship Education In Nigerian Universities", European Journal of Educational Studies 3(1), ISSN 1946-6331, Ozean Publication.

krueger Jr, N. F. (January, 2005). "The Cognitive Psychology of Entrepreneurship". Techniset, Denton, Manchester, DOI: 10.1007/0-387-24519-7_6

Krueger, N., Reilly, M., \& Carsrud, A. (2000). "Competing models of entrepreneurial intentions". Journal of Business Venturing, 15(5-6), 411-432.

Kuratko, D. F. (2005). "The emergence of entrepreneurship education: Development, trends, and challenges." Entrepreneurship Theory and Practice September: 577-597.

Kuratko, D. F. (2014). Entrepreneurship: Theory, process, practice (9th ed.). Mason, OH: Cengage/Southwestern.

Lee, L. \& Wong, P (2005), "Entrepreneurship Education A compendium of Related Issues". NUS Entrepreneurship Centre Working paper,July, 2005.

Mason, C. (2000), "Teaching Entrepreneurship to Undergraduate: Lessons from Leading Centers of Entrepreneurship Education", University of Southampton, Department of Geography.

McClelland. D. C. (1961). The Achieving Society. Free Press, New York in Holienka, M. Holienkova, J. \& Gál, P. (2015). "Entrepreneurial Characteristics of Students in Different Fields of Study: A View from Entrepreneurship Education Perspective". Acta Universitatis Agriculturae et Silviculturae Mendelianae Brunensis, 63(6) http://dx.doi.org/10.11118/actaun201563061879

McMullan, W.E. \& Long, W.A. (1987). "Entrepreneurship education in the nineties. Journal of Business Venturing", 2, 261-275 
Miettinen, A. (2006), "Finnish Survey on Collegiate Entrepreneurship 2006, A Report submitted to Tampere University of Technology Industrial Management", Tampere, Finland, 1-35.

Morrison, A (2001). "Entrepreneurs transcend time: A biographical analysis", Management Decision, 39(9),784791 in Amiri, N.S. \& Marimaei, M. R. (February, 2012). "Concept of entrepreneurship and entrepreneurs traits and characteristics". Scholarly Journal of Business Administration, Vol. 3(2) pp.20-25, Available online http:// www.scholarly-journals.com/SJBA ISSN 2276-7126.

Mustafa, M. B. (2019). 'Factors Stimulating Students to Venture into The Field of Entrepreneurship Towards Producing Entrepreneurs Among University Students". International Journal of Academic Research in Business and Social Sciences, 9(3), 875-883.

Ogbiji, J. E. (2018). Implementation of Entrepreneurship Education Programme in Tertiary Educational Institutions and Graduate Employment in Nigeria: The Perspective of Cross River State, International Journal of Human Resource Studies, Vol. 8, No. 3, ISSN 2162-3058 2018.

Okebukola, P.A.O. (2004). Curriculum Implementation in Nigeria 21stcent, in Noah, AOK, Shonibare, D, OJo, A. A., \& Olujuwon T. (Eds), Curriculum Implementation and Professionalizing Teaching in Nigeria, Lagos: Central Educational services.

Okoro, J. (2008). "Strategies to improve the teaching and learning of business studies in secondary schools in Delta state". Afrwican Journal of Education and Development Studies, 6(2), 48-56

Olorundare, S. \& Kayode, D.J. (2014). Entrepreneurship education in Nigerian universities: A tool for national transformation. Asian Pasific Journal of Educators \& Education, 29, 155-175.

Onyeachu, J. A. E. (2008). Curriculum Implementation at the Primary Education Level, challenges of the 21 stcentury, International Journal of Research and Development 10/1

Ozaralli, N_\& Rivenburgh, N. K. (2016). "Entrepreneurial intention: antecedents to entrepreneurial behavior in the U.S.A. and Turkey". Journal of Global Entrepreneurship Research, 6(3).

Plaschka, G. R. \& Welsch, H. P. (1990). "Emerging Structures in Entrepreneurship Education:

Curricular Designs and Strategies", Entrepreneurship Theory and Practice, 14(3): 55-71.

Postigo, S. \& Tamborini, M. F. (2007). "University Entrepreneurship Education in Argentina: Decade of Analysis”, National Council for Graduate Entrepreneurship Working Paper 014, 1-12.

Price, C. \& Monroe, S. (1993). "Educational training for woman and minority entrepreneurs positively impacts venture growth and economic development." Frontiers of Entrepreneurship Research, Babson College.

Proshare. (2016). Entrepreneurship in Nigeria. Personal communication. retrieved on December 19, 2019 from https://www.proshareng.com/news/Entrepreneurship

Rotter, J. B (1966). "Generalized expectancies for internal versus external control of reinforcement". Psychological Monographs: General and Applied. 80, 1-28. doi:10.1037/h0092976.

Sajjad, S. I., Shafi, H., \& Dad, A. M. (2012). "Impact of Culture on Entrepreneur Intention". Information Management and Business Review, 4(1), 30-34.

Shapero, A., \& Sokol, L. (1982). "Social Dimensions of Entrepreneurship" in: C. Kent, D..Sexton and K. Vesper (eds.). The encyclopedia of entrepreneurship. Englewood Cliffs: Prentice-Hall, 72-90.

Simon, M. \& Shrader, R. C. (2012). Entrepreneurial Actions and Optimistic Overconfidence: The Role of Motivated Reasoning in New Product Introductions. Journal of Business Ventur. 27(3):291-309

Souitaris, V., Zerbinati, S. \& Al-Laham, A. (2007).” Do Entrepreneurship Programmes Raise Entrepreneurial Intention of Science and Engineering Students? The Effect of Learning, Inspiration and Resources". Journal of Business Venturing, 22 (4), 566-591. Students: Education \& Training, 50 (7), 568-581. Universities: The Journal of Private Enterprise, 4(Fall), 103-108.

Tanveeri, M. A., Zafar, S., Shafique, R., Jhangir, M. \& Rizvi, S. (January, 2013). "Motivational Factors and Students Entrepreneurial Intention in Pakistan". Journal of Basic and Applied Scientific Research, from www.textroad.com

Thandi, H. \& Sharma, R. (October, 2003). "MBA Students and Entrepreneurship: An Australian Study of Entrepreneurial Intentions and Actualization, Journal of Institutional Research South East Asia (JIRSEA), 2(1), 12-23

Tomczyk, Ł. \& Vacek, J. (2016). “Entrepreneurship Education - Theoretical Framework". retrieved from https://www.researchgate.net/publication/308967438 on 9th June, 2020.

Undie, J.A., Sule, M. \& Bassey, U. (2012). "Entrepreneurship Education: Trends, Challenges \& Possibilities in Nigerian Higher Education". Journal of Modern Education Review, 2(4), 279-285.

Vesper, K. H., \& Gartner, W. B. (1997). "Measuring progress in entrepreneurship education". Journal of Business Venturing, 12(5), 403-421.

Walstad, W.B. and Kourilsky, M. L. (1999). “Entrepreneurial Attitudes and Knowledge of Black

Youth". Entrepreneurship in Theory and Practice 23(2): 5-18.

Watkins-Marthys, L. (2009). Developing Student-led Entrepreneurship Learning: the South-East England Collaborative Model. Buckinghamshire: Buckinghamshire University. 
Wilkinson, D. (2005). "Entrepreneurial Intentions Survey 2004-2005: An Analysis of the 2004-2005 Student Entrepreneurial Intentions Survey Conducted at Leeds Metropolitan University, the University of Leeds, the University of Huddersfield, the University of Bradford, Sheffield Hallam University, the University of Hull and Trinity and All Saints College. Leeds: Yorkshire Universities Partnership/Yorkshire Forward.

Zaralli, N. O. \& Rivenburgh, N. K. (2016). "Entrepreneurial intention: Antecedents to Entrepreneurial Behavior in the U.S.A. and Turkey", Journal of Global Entrepreneurship Research 6(3), DOI 10.1186/s40497-016$0047-$

Zraa, Kavanagh \& Hartle (2011). "Teaching Accounting in the New Millennium". A Conference Proceeding at the Cambridge Business and Economics Conference (CBEC), held in June 27 -29 at Cambridge University, UK.

Zeithaml, C. P. \& Rice, G. H. (1987). "Entrepreneurship/Small Business Education in American Universities." Journal of Small Business Management, 25(1), 44 - 50. 